\title{
Endosymbiotic microorganisms of aphids (Hemiptera: Sternorrhyncha: Aphidoidea): Ultrastructure, distribution and transovarial transmission
}

\author{
AnNa MICHALIK ${ }^{1}$, Teresa SZKLARZEWICZ ${ }^{1}$, WŁadystaWa JANKOWSKA ${ }^{1}$ and Karina WIECZOREK ${ }^{2}$
}

\begin{abstract}
${ }^{1}$ Department of Developmental Biology and Morphology of Invertebrates, Institute of Zoology, Jagiellonian University, Gronostajowa 9,30-387 Kraków, Poland; e-mails: a.michalik@uj.edu.pl; teresa.szklarzewicz@uj.edu.pl; ada.jankowska@uj.edu.pl

${ }^{2}$ Department of Zoology, Faculty of Biology and Environmental Protection, University of Silesia, Bankowa 9, 40-007 Katowice, Poland; e-mail: karina.wieczorek@us.edu.pl
\end{abstract}

Key words. Aphidoidea, endosymbiotic bacteria, bacteriocytes, transovarial transmission of endosymbiotic bacteria

\begin{abstract}
The ultrastructure, distribution and transovarial transmission of endosymbiotic bacteria in representatives of six aphid families: Eriosomatidae (Pemphigus spyrothecae, Prociphilus fraxini), Anoeciidae [Anoecia (Anoecia) corni], Drepanosiphidae [Mindarus abietinus, Sipha (Rungsia) maydis, Clethrobius comes, Myzocallis (Lineomyzocallis) walshii], Thelaxidae (Thelaxes dryophila), Aphididae (Delphiniobium junackianum, Aphis viburni, Cavariella theobaldi, Macrosiphoniella tanacetaria) and Lachnidae (Schizolachnus pineti, Eulachnus rileyi) were studied at the ultrastructural level. The ovaries of aphids are accompanied by large organs termed bacteriomes that consist of giant cells termed bacteriocytes. The bacteriocyte cytoplasm is tightly packed with endosymbiotic bacteria. Ultrastructural observations have shown that the bacteria Buchnera aphidicola (primary symbiont of aphids) present in various species are characterized by significant differences in both size and organization of their cytoplasm. In the aphids, Prociphilus fraxini, Sipha (Rungsia) maydis, Thelaxes dryophila, Aphis viburni, Cavariella theobaldi, Macrosiphoniella tanacetaria, Eulachnus rileyi and Schizolachnus pineti, in addition to Buchnera aphidicola, secondary endosymbionts are also present. The bacteriocytes containing secondary endosymbionts are less numerous than those with Buchnera. In Eulachnus rileyi (Lachnidae), in addition to primary and secondary endosymbionts, there is a third type of microorganism. In all species examined both the primary and secondary endosymbionts are transovarially transmitted from mother to offspring.
\end{abstract}

\section{INTRODUCTION}

Many insects live in symbiotic associations with prokaryotic (i.e. bacteria) or eukaryotic (i.e. yeasts) microorganisms. Numerous extensive studies have revealed that endosymbiotic microorganisms may occur in the body of a host insect extracellularly (e.g. in the gut lumen) or intracellularly (in specialized cells of mesodermal origin termed bacteriocytes or mycetocytes) (see Buchner, 1965; Douglas, 1989, 1998; Moran \& Baumann, 2000; Ishikawa, 2003; Baumann, 2005; Kikuchi, 2009 for further details). Bacteriocytes contain bacteria, whereas mycetocytes harbour yeasts. Both bacteriocytes and mycetocytes are large, polyploid cells that as a rule are integrated into large organs termed bacteriomes or mycetomes, respectively. Buchner (1965) postulated that in insects two categories of endosymbionts may be present: obligate ones (currently termed primary endosymbionts or P-symbionts) and accessory ones (currently termed facultative endosymbionts, secondary endosymbionts or S-symbionts). The primary endosymbionts occur in all specimens of a given species and are always transovarially (i.e. vertically, maternally) transmitted from one generation to the next. The occurrence of primary endosymbiotic microorganisms in the body of plant sap-sucking hemipterans is connected with their diet, which is deficient in amino acids (Douglas, 1989, 1998; Douglas \& Prosser, 1992; Lai et al., 1994; Sasaki \& Ishikawa, 1995; Baumann et al., 1995). The presence of primary endosymbionts seems to be indispensable since they are necessary for both survival and reproduction of host insects. In contrast to primary endosymbionts, secondary ones may occur not only within bacteriocytes but also in other cells (e.g. fat body cells) or even free in the haemolymph (Moran \& Telang, 1998; Fukatsu et al., 2000; Oliver et al., 2006, 2010). The secondary endosymbionts are, as a rule, only in individuals of some subpopulations. The role of secondary endosymbionts is still unclear, but results of recent studies indicate that aphids that possess secondary endosymbionts are more resistant to heat stress (Montlor et al., 2002), attack by parasitic hymenopterans (Oliver et al., 2003; Vorburger et al., 2010) and infection by fungal pathogens (Scarborough et al., 2005) than those that lack them. It is also suggested that secondary endosymbionts may compensate for the loss of the primary endosymbiont of aphids, the bacterium Buchnera (see below) and are able to supplement insufficient provisioning of amino acids usually provided by Buchnera (Koga et al., 2003; Burke et al., 2009). The secondary endosymbionts may be transmitted either vertically or horizontally (Buchner, 1965).

It is believed that associations between insects and primary endosymbionts are results of single, ancient infections (Buchner, 1965). Analysis of 16S rDNA sequences of the primary endosymbiont of aphids, Buchnera aphidicola, revealed that the association between aphids and their primary endosymbiont resulted from an infection that occurred 200 to 250 million years ago (Unterman et al., 1989; Moran \& Baumann, 1994; Martinez-Torres et 
TABLE 1. List of the species studied.

\begin{tabular}{|c|c|c|c|c|}
\hline Species & Family & Place of collection & Date of collection & Host plant \\
\hline \multirow{2}{*}{ Pemphigus spyrothecae } & \multirow{2}{*}{ Eriosomatidae } & Katowice & May, 2007, 2008 & Populus nigra \\
\hline & & Katowice & October, 2008 & Populus nigra \\
\hline Prociphilus fraxini & Eriosomatidae & Gliwice, Cracow & $\begin{array}{l}\text { April, May, } 2008 \\
\text { October, } 2009 \\
\end{array}$ & Fraxinus excelsior \\
\hline Anoecia (Anoecia) corni & Anoeciidae & Ojcow, Katowice, Cracow & $\begin{array}{c}\text { August, } 2004 \\
\text { June, 2007 } \\
\text { October, 2006, } 2010\end{array}$ & Cornus sanguinea \\
\hline Mindarus abietinus & Drepanosiphidae & Ojcow, Gorce, Myslenice & June, 2007, 2009, 2010 & Abies alba \\
\hline Sipha (Rungsia) maydis & Drepanosiphidae & $\begin{array}{c}\text { Zawada near Czestochowa } \\
\text { Dobrowa Gornicza }\end{array}$ & September, October, 2009 & Arrhenatherum elatius \\
\hline Clethrobius comes & Drepanosiphidae & Katowice & $\begin{array}{l}\text { April, August, } 2009 \\
\text { October, 2008, } 2009\end{array}$ & Alnus incana \\
\hline $\begin{array}{l}\text { Myzocallis (Lineomyzocallis) } \\
\text { walshii }\end{array}$ & Drepanosiphidae & Katowice & October, 2005 & Quercus rubra \\
\hline Thelaxes dryophila & Thelaxidae & Katowice & May, 2007 & Quercus robur \\
\hline Delphiniobium junackianum & Aphididae & Ojcow & May, September, 2005 & Aconitum firmum \\
\hline Aphis viburni & Aphididae & $\begin{array}{l}\text { Kasna Gorna near Tarnow } \\
\text { Ojcow, }\end{array}$ & $\begin{array}{c}\text { June, October, 2006, } \\
2010 \\
\end{array}$ & Viburnum opulus \\
\hline Cavariella theobaldi & Aphididae & Kotlina Nowotarska & May, September, 2003 & Heracleum sphondylium \\
\hline Macrosiphoniella tanacetaria & Aphididae & $\begin{array}{c}\text { Borne-Sulimowo near } \\
\text { Szczecinek }\end{array}$ & June, 2004 & Tanacetum vulgare \\
\hline Schizolachnus pineti & Lachnidae & Bochnia & July, October, 2009, 2010 & Pinus sylvestris \\
\hline Eulachnus rileyi & Lachnidae & Ustron & May, September, 2009 & Pinus sylvestris \\
\hline
\end{tabular}

al., 2001; Moran et al., 2008). In contrast to primary endosymbionts, the associations between insects and secondary endosymbionts are results of more recent multiple and independent infections (Moran \& Telang, 1998; Sandström et al., 2001; Thao \& Baumann, 2004; Baumann, 2006).

Within aphids, only representatives of the family Phylloxeridae (superfamily Phylloxeroidea) do not contain endosymbiotic microorganisms (Buchner, 1965; Szklarzewicz et al., 2009). Aphids belonging to the family Adelgidae (superfamily Adelgoidea) may harbour gamma- or/and betaproteobacterial endosymbionts (Toenshoff et al., 2012a, b; von Dohlen et al., 2013). In aphids belonging to the superfamily Aphidoidea (except for some representatives of the family Hormaphididae) a gammaproteobacterium, Buchnera aphidicola, is present (see Baumann et al., 1995; Douglas, 2003 for further details).

Results of molecular analyses have revealed that during the co-evolution between the bacterium Buchnera aphidicola and aphids, the bacterial genome underwent a process of reduction, which resulted in the loss of some genes, e.g. those controlling the synthesis of nonessential amino acids, sterols and cell wall components, and controlling regulation and cell defense (see Ishikawa, 2003; Latorre \& Moya, 2006 for further details). As a consequence, (1) the genome of B. aphidicola is one seventh of that of its close relative, Escherichia coli and (2) these endosymbionts are not able to live outside their host (Charles \& Ishikawa, 1999). In contrast to genes for the synthesis of nonessential amino acids that have been lost, there are multiple copies of the genes responsible for the synthesis of essential amino acids in the genome of $B$. aphidicola (Lai et al., 1994). Since the bacteria B. aphidicola living in different species of aphids evolved independently from each other (i.e. without gene exchange between bacteria in different hosts), the comparison of gene sequences (mainly $16 \mathrm{~S}$ rDNA) of these endosymbionts appeared to be very useful to construct the phylogenetic tree of aphids (Clark et al., 2000; Normark, 2000; Martinez-Torres et al., 2001; Hypša \& Novákova, 2009; Jousselin et al., 2009; Perez-Brocal et al., 2011; Liu et al., 2013; Novákova et al., 2013).

Although endosymbiotic microorganisms of aphids have been extensively studied, there are, however, very few studies of their ultrastructure, localization in the host's body and mode of transmission to the next generation. This fact prompted us to investigate aspects of symbiosis listed above both in viviparous and oviparous generations of six families of aphids belonging to the superfamily Aphidoidea.

\section{MATERIAL AND METHODS}

\section{Insects}

Viviparous and oviparous females of 14 species belonging to six families of the Aphidoidea were examined: Eriosomatidae [Pemphigus spyrothecae Passerini, 1856; Prociphilus fraxini (Fabricius, 1777)], Anoeciidae [Anoecia (Anoecia) corni (Fabricius, 1775)], Drepanosiphidae [Mindarus abietinus Koch, 1857; Sipha (Rungsia) maydis Passerini, 1860; Clethrobius comes (Walker, 1848); Myzocallis (Lineomyzocallis) walshii (Monell 


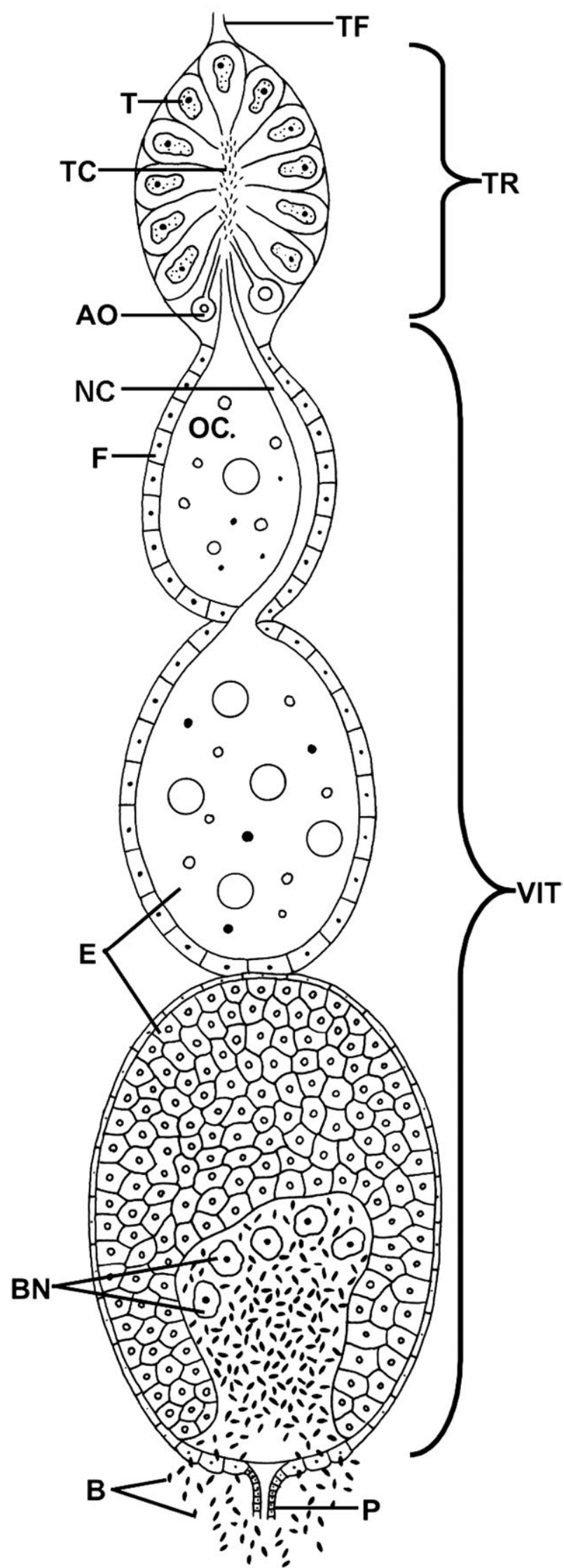

Fig. 1. Schematic representation of the structure of an ovary and transovarial transmission of endosymbiotic bacteria in viviparous generations of aphids. Abbreviations: $\mathrm{AO}$ - arrested oocyte, $\mathrm{B}$ - endosymbiotic bacteria, $\mathrm{BN}$ - bacteriocyte nuclei, $\mathrm{B}$ - embryo, $\mathrm{F}$ - follicular epithelium, $\mathrm{NC}$ - nutritive cord, OC oocyte, $\mathrm{P}$ - pedicel, $\mathrm{T}$ - trophocyte, $\mathrm{TC}$ - trophic core, TF - terminal filament, TR - tropharium, VIT - vitellarium

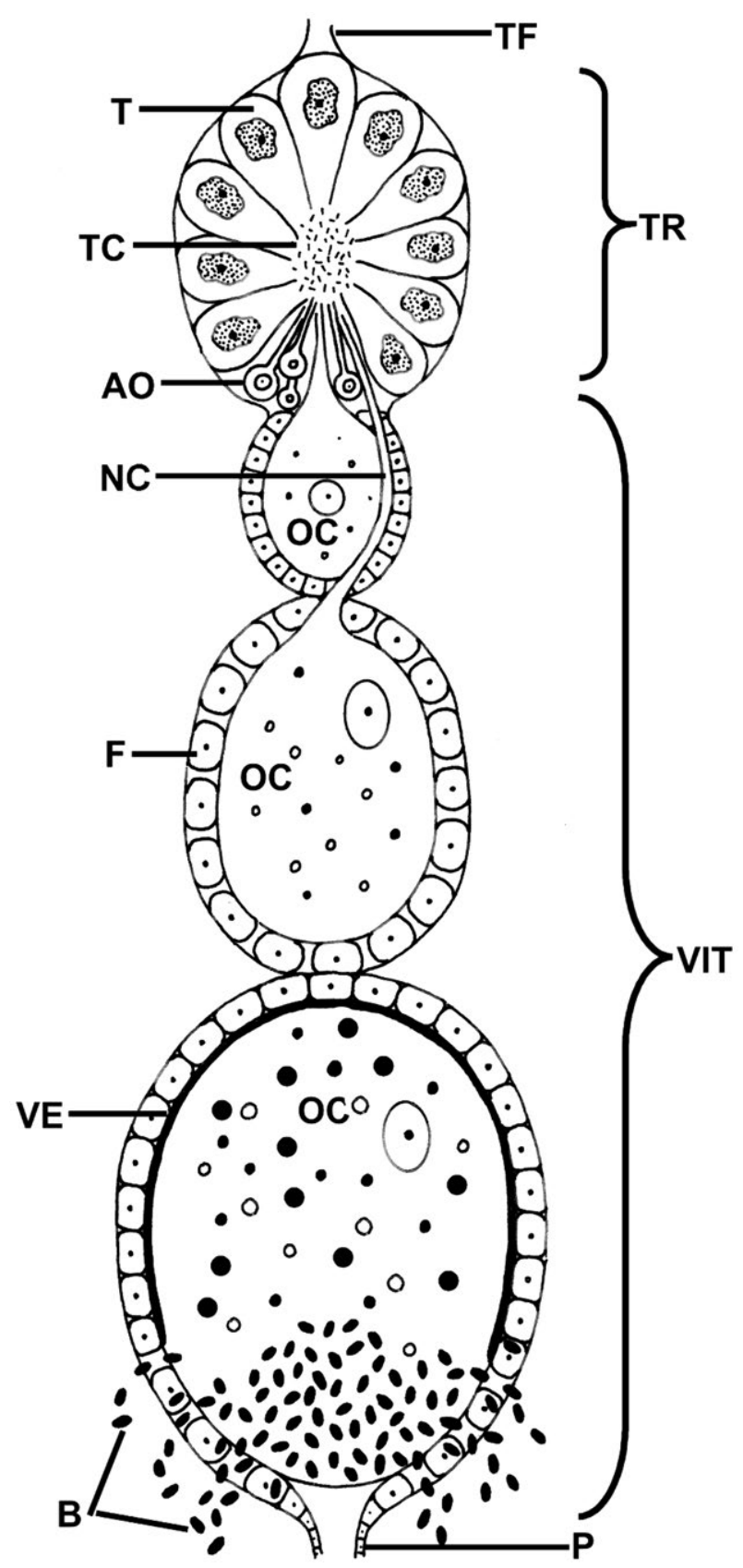

Fig. 2. Schematic representation of the structure of an ovary and transovarial transmission of endosymbiotic bacteria in oviparous generation of aphids. Abbreviations: AO - arrested oocyte, B - endosymbiotic bacteria, F - follicular epithelium, $\mathrm{NC}$ - nutritive cord, OC - oocyte, $\mathrm{P}$ - pedicel, $\mathrm{T}$ - trophocyte, $\mathrm{TC}$ - trophic core, TF - terminal filament, TR - tropharium, VIT - vitellarium, VE - egg envelopes.

in Riley \& Monell, 1879)], Thelaxidae [Thelaxes dryophila (Schrank, 1801)], Aphididae [Delphiniobium junackianum (Karsch, 1887); Aphis viburni Scopoli, 1763; Cavariella theobaldi (Gillette \& Bragg, 1918); Macrosiphoniella tanacetaria (Kaltenbach, 1843)], Lachnidae [Schizolachnus pineti (Fabricius, 1781); Eulachnus rileyi (Williams, 1911)]. All species were collected in the south of Poland. For each species ten specimens were examined.

Place, date of collection and the host plant of the species studied are summarized in Table 1. 

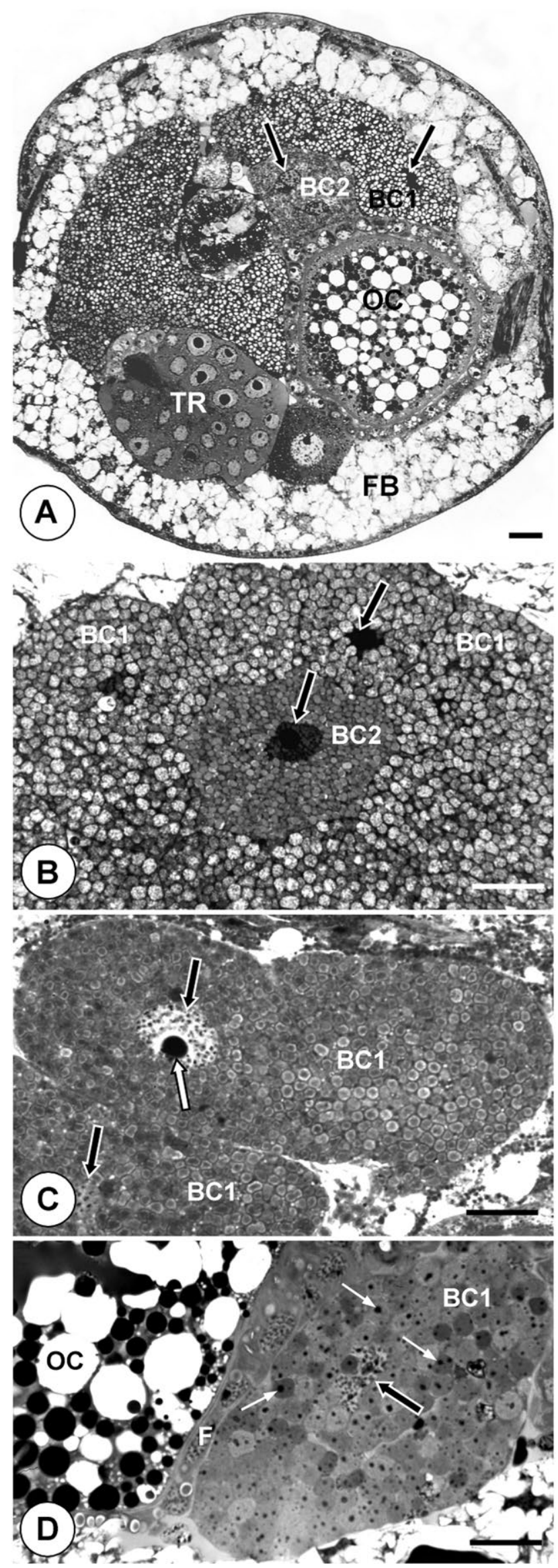

Light and electron microscopy (TEM)

Females of all species studied were fixed in $2.5 \%$ glutaraldehyde in $0.1 \mathrm{M}$ phosphate buffer ( $\mathrm{pH}$ 7.4). Next, the material was rinsed in a mixture of the buffer and sucrose $(5.8 \mathrm{~g} / 100 \mathrm{ml})$ and postfixed in $1 \%$ osmium tetroxide in the same buffer. After dehydration in a graded series of ethanol and acetone, the material was embedded in epoxy resin Epon 812 (Serva, Heidelberg, Germany). Semithin sections were stained with $1 \%$ methylene blue in $1 \%$ borax, examined and photographed using Leica DMR and Nikon Eclipse 80i light microscopes. Ultrathin sections were contrasted with uranyl acetate and lead citrate and examined and photographed using a JEM 100 SX electron microscope at $80 \mathrm{kV}$.

\section{RESULTS}

\section{Gross morphology of the ovary}

The ovaries of aphids consist of several telotrophic ovarioles (Figs 1, 2). An individual ovariole is composed of four well-defined regions: a terminal filament, tropharium (trophic chamber), vitellarium and pedicel (ovariolar stalk) (Figs 1,2). The latter joins the ovariole to the lateral oviduct. The tropharium consists of individual trophocytes and early previtellogenic oocytes termed arrested oocytes. The central part of the tropharium is occupied by a cell-free area termed the trophic core (Figs 1, 2). The vitellarium contains linearly arranged ovarian follicles (Figs 1, 2). Each follicle encloses a developing oocyte surrounded by a onelayered follicular epithelium (Figs 1, 2). All oocytes (arrested and those in the vitellarium) are connected to the trophic core by nutritive cords (Figs 1, 2). In oviparous females oocytes develop through three stages: previtellogenesis, vitellogenesis and choriogenesis (Fig. 2). During previtellogenic growth RNAs (synthesized by trophocytes) are transported along the nutritive cord into the cytoplasm of the oocyte. During vitellogenesis the volume of the oocyte increases due to the accumulation of reserve substances (i.e. yolk granules and lipid droplets) in its cytoplasm. During choriogenesis, as a result of the

Fig. 3. Distribution of endosymbiotic microorganisms. A Anoecia (Anoecia) corni (Anoeciidae). Oviparous generation. Cross section of the abdomen. In the body cavity of a mature female bacteriocytes with endosymbiotic microorganisms fill the spaces between internal organs. Abbrev.: BC1 - bacteriocyte with bacteria Buchnera aphidicola (primary endosymbiont), $\mathrm{BC} 2$ - bacteriocyte with secondary endosymbionts, FB - fat body, OC - oocyte, TR - tropharium, black arrow - bacteriocyte nucleus. Methylene blue, scale bar - $20 \mu \mathrm{m}$. B Anoecia (Anoecia) corni (Anoeciidae). Oviparous generation. Bacteriome. Abbrev.: BC1 - bacteriocyte with Buchnera aphidicola. $\mathrm{BC} 2$ - bacteriocyte with secondary endosymbionts, black arrow - bacteriocyte nucleus. Methylene blue, scale bar $20 \mu \mathrm{m}$. C - Thelaxes dryophila (Thelaxidae). Viviparous generation. Bacteriocytes with Buchnera aphidicola (BC1), black arrow - bacteriocyte nucleus, white arrow - bacteriocyte nucleous. Methylene blue, scale bar $-20 \mu \mathrm{m}$. D - Prociphilus fraxini (Eriosomatidae). Oviparous generation. Fragment of the bacteriocyte with Buchnera aphidicola (BC1). Abbrev.: OC - oocyte, $\mathrm{F}$ - follicular epithelium, black arrow - bacteriocyte nucleus, white arrows - electron-dense aggregates. Methylene blue, scale bar $-20 \mu \mathrm{m}$. 


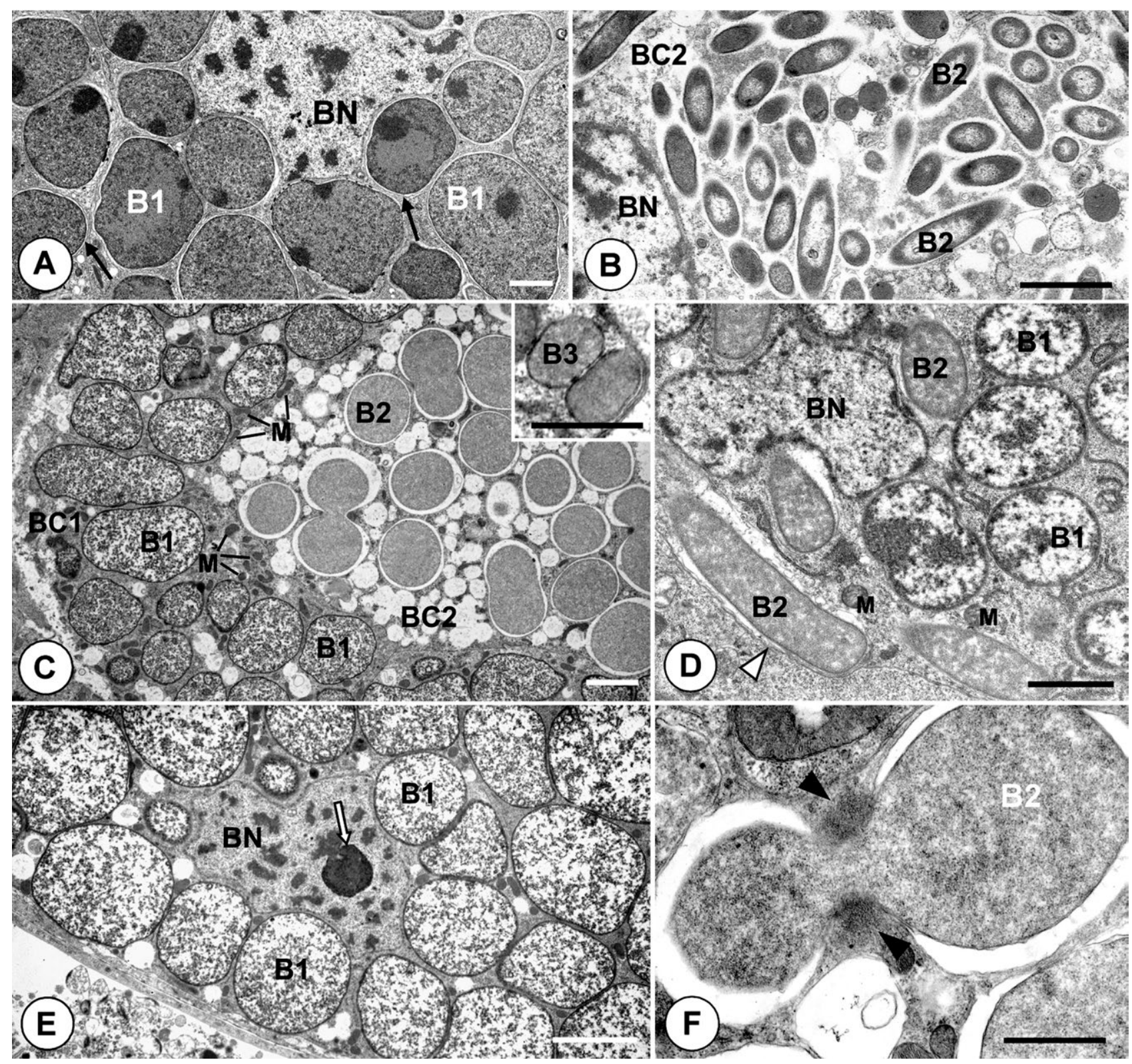

Fig. 4. Ultrastructure of endosymbiotic microorganisms. A - Prociphilus fraxini (Eriosomatidae). Oviparous generation. Fragment of the bacteriocyte with bacteria Buchnera aphidicola. Abbrev.: B1 - bacterium Buchnera aphidicola, BN - bacteriocyte nucleus, black arrow - perisymbiotic membrane. TEM, scale bar $-2 \mu \mathrm{m}$. B - Cavariella theobaldi (Aphididae). Viviparous generation. Fragment of the bacteriocyte with secondary endosymbionts (BC2). Abbrev.: B2 - secondary endosymbiont, BN - bacteriocyte nucleus. TEM, scale bar $-2 \mu \mathrm{m}$. C - Schizolachnus pineti (Lachnidae). Viviparous generation. Fragment of the bacteriome containing bacteriocytes with bacteria Buchnera aphidicola and bacteriocyte with secondary endosymbionts. Abbrev.: B1 - bacterium Buchnera aphidicola, $\mathrm{B} 2$ - secondary endosymbiont, $\mathrm{BC} 1$ - bacteriocyte with bacteria Buchnera aphidicola, $\mathrm{BC} 2$ - bacteriocyte with secondary endosymbionts, $\mathrm{M}$ - mitochondria. TEM, scale bar $-3 \mu \mathrm{m}$. Insert: Eulachnus rileyi (Lachnidae). Viviparous generation. Third type of microorganism (B3) in the cytoplasm of the bacteriocyte containing the bacterium Buchnera aphidicola. TEM, scale bar - 1 $\mu \mathrm{m}$. D - Aphis viburni (Aphididae). Viviparous generation. Primary and secondary endosymbionts in same bacteriocyte. Abbrev.: B1 - bacterium Buchnera aphidicola, B2 - secondary endosymbiont, BN - bacteriocyte nucleus, $\mathrm{M}$ - mitochondrium, white arrowhead - bacteriocyte membrane, TEM, scale bar - $2 \mu \mathrm{m}$. E - Pemphigus spyrothecae (Eriosomatidae). Viviparous generation. Fragment of the bacteriocyte with bacteria Buchnera aphidicola. Abbrev.: B1 - bacterium Buchnera aphidicola, BN - bacteriocyte nucleus, white arrow - bacteriocyte nucleous. TEM, scale bar $-4 \mu \mathrm{m}$. F - Eulachnus rileyi (Lachnidae). Viviparous generation. Dividing secondary bacterium (B2); black arrowheads - electron-dense material. TEM, scale bar $-1 \mu \mathrm{m}$.

synthetic activity of follicular cells the oocyte becomes covered with egg envelopes (for a detailed description of ovaries of aphids see Büning, 1985; Szklarzewicz et al., 2000, 2009; Michalik et al., 2013). In viviparous females the oocyte growth stops at the stage of previtellogenesis.
Soon after previtellogenesis the nucleus undergoes a series of synchronous divisions resulting in the formation of an embryo (Fig. 1). 
TABLE 2. Sizes of primary endosymbiotic bacteria (Buchnera aphidicola) in the species of aphids studied $(\bar{x}-$ mean, S.D. - standard deviation).

\begin{tabular}{|c|c|c|c|c|c|c|c|}
\hline No. & Species & Family & $\begin{array}{l}\text { Diameter } \\
\bar{x}[\mu \mathrm{m}]\end{array}$ & $\mathrm{N}$ & $\begin{array}{l}\text { Min. } \\
{[\mu \mathrm{m}]}\end{array}$ & $\begin{array}{l}\text { Max. } \\
{[\mu \mathrm{m}]}\end{array}$ & S.D. \\
\hline 1. & Pemphigus spyrothecae & Eriosomatidae & 4.53 & 19 & 4.04 & 5.33 & 0.33 \\
\hline 2. & Prociphilus fraxini & Eriosomatidae & 4.14 & 19 & 3.14 & 5.23 & 0.62 \\
\hline 3. & Anoecia (Anoecia) corni & Anoeciidae & 3.19 & 18 & 2.33 & 3.9 & 0.52 \\
\hline 4. & Mindarus abietinus & Drepanosiphidae & 3.14 & 17 & 2.41 & 3.5 & 0.24 \\
\hline 5. & Sipha (Rungsia) maydis & Drepanosiphidae & 2.48 & 19 & 2 & 3.14 & 0.32 \\
\hline 6. & Clethrobius comes & Drepanosiphidae & 3.92 & 18 & 3.1 & 4.8 & 0.58 \\
\hline 7. & Myzocallis (Lineomyzocallis) walshii & Drepanosiphidae & 2.58 & 19 & 2.25 & 2.88 & 0.19 \\
\hline 8. & Thelaxes dryophila & Thelaxidae & 3.3 & 19 & 2.85 & 4.32 & 0.32 \\
\hline 9. & Delphinobium junackianum & Aphididae & 3.2 & 19 & 2.57 & 3.97 & 0.38 \\
\hline 10. & Aphis viburni & Aphididae & 2.63 & 19 & 2.14 & 3.45 & 0.3 \\
\hline 11. & Cavariella theobaldi & Aphididae & 2.09 & 16 & 1.9 & 2.55 & 0.2 \\
\hline 12. & Macrosiphoniella tanacetaria & Aphididae & 2.51 & 19 & 2.17 & 3.11 & 0.24 \\
\hline 13. & Eulachnus rileyi & Lachnidae & 2.69 & 19 & 2.5 & 2.92 & 0.1 \\
\hline 14. & Schizolachnus pineti & Lachnidae & 3.45 & 19 & 2.68 & 3.97 & 0.33 \\
\hline
\end{tabular}

\section{Ultrastructure and distribution of endosymbiotic microorganisms}

In the body of both viviparous and oviparous females of all the species of aphids studied large organs termed bacteriomes occur in the close vicinity of the ovaries (Fig. 3A). The bacteriomes consist of numerous giant cells termed bacteriocytes (Fig. 3A, B, C, D). The bacteriocyte cytoplasm is tightly packed with endosymbiotic bacteria (Figs 3A-D, 4A-E). In most aphids there are two types of bacteriocytes: one type contains the bacterium Buchnera aphidicola (Fig. 3A-D) and the other secondary symbionts (Fig. 3A, B). Both types of bacteriocytes are usually spherical with a diameter of about $80 \mu \mathrm{m}$. The bacteriocytes possess large, spherical or amoeboid nuclei with single nucleoli and aggregations of heterochromatin (Figs $3 \mathrm{~B}, \mathrm{C}, 4 \mathrm{~A}, \mathrm{D}, \mathrm{E})$. The bacterium $\mathrm{B}$. aphidicola is usually spherical or oval (Figs 3A-C, 4D, E), but may be also ameboid in shape (Figs 3D, 4A, C). Their diameter ranges from 1.9 to $5.33 \mu \mathrm{m}$ (see Table 2). In representatives of the family Eriosomatidae, the size of B. aphidicola is much larger than in the other aphids studied. In most species of aphids the cytoplasm of $B$. aphidicola is not differentiated into distinct zones (Fig. 4 C, E). In the cytoplasm of these bacteria, in some species of aphids (Prociphilus

TABLE 3. Sizes of the secondary endosymbiotic bacteria in the species of aphids studied $(\bar{x}-$ mean, S.D. - standard deviation).

\begin{tabular}{|c|c|c|c|c|c|c|c|c|c|c|c|}
\hline Species & Family & $\begin{array}{l}\text { Length } \\
\bar{x}[\mu \mathrm{m}]\end{array}$ & $\mathrm{N}$ & $\begin{array}{l}\text { Min. } \\
{[\mu \mathrm{m}]}\end{array}$ & $\begin{array}{l}\text { Max. } \\
{[\mu \mathrm{m}]}\end{array}$ & S.D. & $\begin{array}{l}\text { Diameter } \\
\bar{x}[\mu \mathrm{m}]\end{array}$ & $\mathrm{N}$ & $\begin{array}{l}\text { Min. } \\
{[\mu \mathrm{m}]}\end{array}$ & $\begin{array}{l}\text { Max. } \\
{[\mu \mathrm{m}]}\end{array}$ & S.D. \\
\hline 1. Pemphigus spyrothecae & Eriosomatidae & - & - & - & - & - & - & - & - & - & - \\
\hline 2. Prociphilus fraxini & Eriosomatidae & 5.14 & 15 & 4.6 & 5.8 & 0.29 & 3.02 & 16 & 2.8 & 3.2 & 0.14 \\
\hline 3. Anoecia (Anoecia) corni & Anoeciidae & - & - & - & - & - & 2.08 & 17 & 1.97 & 2.19 & 0.06 \\
\hline 4. Mindarus abietinus & Drepanosiphidae & - & - & - & - & - & - & - & - & - & - \\
\hline 5. Sipha (Rungsia) maydis & Drepanosiphidae & 7.56 & 17 & 6.3 & 8.45 & 0.63 & 1.51 & 17 & 1.39 & 1.7 & 0.08 \\
\hline 6. Clethrobius comes & Drepanosiphidae & - & - & - & - & - & - & - & - & - & - \\
\hline $\begin{array}{l}\text { 7. Myzocallis (Lineomyzocallis) } \\
\text { walshii }\end{array}$ & Drepanosiphidae & - & - & - & - & - & - & - & - & - & - \\
\hline 8. Thelaxes dryophila & Thelaxidae & - & - & - & - & - & 2.51 & 17 & 2.17 & 3.3 & 0.32 \\
\hline 9. Delphinobium junackianum & Aphididae & - & - & - & - & - & - & - & - & - & - \\
\hline 10. Aphis viburni & Aphididae & 4.91 & 17 & 3.85 & 5.78 & 0.5 & 0.58 & 17 & 0.47 & 0.66 & 0.05 \\
\hline 11. Cavariella theobaldi & Aphididae & 3.56 & 17 & 3 & 4.09 & 0.33 & 0.66 & 17 & 0.52 & 0.85 & 0.11 \\
\hline 12. Macrosiphoniella tanacetaria & Aphididae & 7.01 & 17 & 6.3 & 7.8 & 0.4 & 1 & 17 & 0.7 & 1.2 & 0.16 \\
\hline $\begin{array}{l}\begin{array}{l}\text { Eulachnus rileyi } \\
\text { secondary endosymbionts } 1\end{array} \\
\end{array}$ & Lachnidae & - & - & - & - & - & 2.3 & 17 & 2 & 2.8 & 0.21 \\
\hline $\begin{array}{l}\text { Eulachnus rileyi } \\
\text { secondary endosymbionts } 2\end{array}$ & Lachnidae & 1.1 & 6 & 0.9 & 1.3 & 0.14 & 0.41 & 6 & 0.39 & 0.43 & 0.014 \\
\hline 14. Schizolachnus pineti & Lachnidae & - & - & - & - & - & 3.55 & 17 & 3 & 4.17 & 0.31 \\
\hline
\end{tabular}


TABLE 4. Types and localization of additional microorganisms (secondary symbionts and a third type of bacteria) in the aphids studied.

\begin{tabular}{|c|c|c|c|c|}
\hline No. & Species & Family & $\begin{array}{l}\text { Types of additional } \\
\text { microorganisms }\end{array}$ & $\begin{array}{l}\text { Localization of additional } \\
\text { microorganisms }\end{array}$ \\
\hline 1. & Pemphigus spyrothecae & Eriosomatidae & absent & - \\
\hline 2. & Prociphilus fraxini & Eriosomatidae & $\begin{array}{l}\text { rod-shaped secondary } \\
\text { endosymbionts }\end{array}$ & in separate bacteriocytes \\
\hline 3. & Anoecia (Anoecia) corni & Anoeciidae & $\begin{array}{l}\text { spherical secondary } \\
\text { endosymbionts }\end{array}$ & in separate bacteriocytes \\
\hline 4. & Mindarus abietinus & Drepanosiphidae & absent & - \\
\hline 5. & Sipha (Rungsia) maydis & Drepanosiphidae & $\begin{array}{l}\text { rod-shaped secondary } \\
\text { endosymbionts }\end{array}$ & in separate bacteriocytes \\
\hline 6. & Clethrobius comes & Drepanosiphidae & absent & - \\
\hline 7. & Myzocallis (Lineomyzocallis) walshii & Drepanosiphidae & absent & - \\
\hline 8. & Thelaxes dryophila & Thelaxidae & $\begin{array}{l}\text { spherical secondary } \\
\text { endosymbionts }\end{array}$ & in separate bacteriocytes \\
\hline 9. & Delphinobium junackianum & Aphididae & absent & - \\
\hline 10. & Aphis viburni & Aphididae & $\begin{array}{l}\text { rod-shaped secondary } \\
\text { endosymbionts }\end{array}$ & $\begin{array}{l}\text { in separate bacteriocytes and bacte- } \\
\text { riocytes with Buchnera aphidicola }\end{array}$ \\
\hline 11. & Cavariella theobaldi & Aphididae & $\begin{array}{l}\text { rod-shaped secondary } \\
\text { endosymbionts }\end{array}$ & in separate bacteriocytes \\
\hline 12. & Macrosiphoniella tanacetaria & Aphididae & $\begin{array}{c}\text { rod-shaped secondary } \\
\text { endosymbionts }\end{array}$ & in separate bacteriocytes \\
\hline \multirow{2}{*}{13.} & \multirow{2}{*}{ Eulachnus rileyi } & \multirow{2}{*}{ Lachnidae } & $\begin{array}{l}\text { spherical secondary } \\
\text { endosymbionts }\end{array}$ & in separate bacteriocytes \\
\hline & & & small, rod-shaped bacteria & $\begin{array}{c}\text { in bacteriocytes with Buchnera } \\
\text { aphidicola }\end{array}$ \\
\hline 14. & Schizolachnus pineti & Lachnidae & $\begin{array}{l}\text { spherical secondary } \\
\text { endosymbionts }\end{array}$ & in separate bacteriocytes \\
\hline
\end{tabular}

fraxini, Aphis viburni), there are electron-dense aggregates (Figs 3D, 4A, D).

In most of the species studied, in addition to B. aphidicola, there are secondary endosymbionts. As a rule they are localized in separate bacteriocytes, which are less numerous than those containing B. aphidicola (Figs 3A, $\mathrm{B}, 4 \mathrm{~B})$. There is one exception to this rule, Aphis viburni (Aphididae). In this species secondary endosymbionts occur both in their own bacteriocytes, but also in the bacteriocytes containing B. aphidicola (Fig. 4D).

In the aphids Anoecia (Anoecia) corni (Anoeciidae), Schizolachnus pineti (Lachnidae) and Eulachnus rileyi (Lachnidae) bacteriocytes with secondary endosymbionts are surrounded by those containing $B$. aphidicola (Fig. 3A, B, 4C). Secondary endosymbionts are characterized by various shapes. In the aphids Anoecia (Anoecia) corni (Anoeciidae), Eulachnus rileyi (Lachnidae), Schizolachnus pineti (Lachnidae) and Thelaxes dryophila (Thelaxidae) they are spherical and measure from 1.97 to $4.17 \mu \mathrm{m}$ in diameter. These bacteria are characterized by dark, more homogeneous cytoplasm than that of $B$. aphidicola (Fig. 4C, F). Secondary endosymbionts of Aphis viburni (Aphididae), Cavariela theobaldi (Aphididae), Macrosiphoniella tanacetaria (Aphididae), Sipha (Rungsia) maydis (Drepanosiphidae) and Prociphilus fraxini (Eriosomatidae) are rod-shaped (Fig. 4B, D). They measure from 3 to $8.45 \mu \mathrm{m}$ in length and from 0.47 to 3.2 $\mu \mathrm{m}$ in diameter (Table 3). In the body of Delphiniobium junackianum (Aphididae), Clethrobius comes (Drepanosiphidae), Myzocallis (Lineomyzocallis) walshii (Drepanosiphidae) and Pemphigus spyrothecae (Eriosomatidae) only B. aphidicola is present (Fig. 4E).

In bacteriocytes of Eulachnus rileyi (Lachnidae), in addition to the primary and secondary endosymbionts, a third type of microorganism occurs (Fig. 4C insert). They are bacteria and occur in the same bacteriocytes as $B$. aphidicola but are significantly less numerous than $B$. aphidicola. They are ovoid in shape, $1.1 \mu \mathrm{m}$ long and $0.41 \mu \mathrm{m}$ in diameter (see Table 3 ). The data on these additional microorganisms in the aphids studied are summarized in Table 4.

Ultrastructural observations indicate that endosymbionts are enclosed by three membranes: two are their own membranes and the third, outer (perisymbiotic) membrane is derived from the host (Fig. 4A).

Both in the bacteriocytes and oocytes all the endosymbiotic microorganisms reproduce by binary fission (Figs 4 C, F, 6F insert).

\section{Transovarial transmission of endosymbiotic microorganisms}

Both $B$. aphidicola and the secondary endosymbionts in the species of aphids studied are transovarially transmitted from one generation to the next. The moment of 


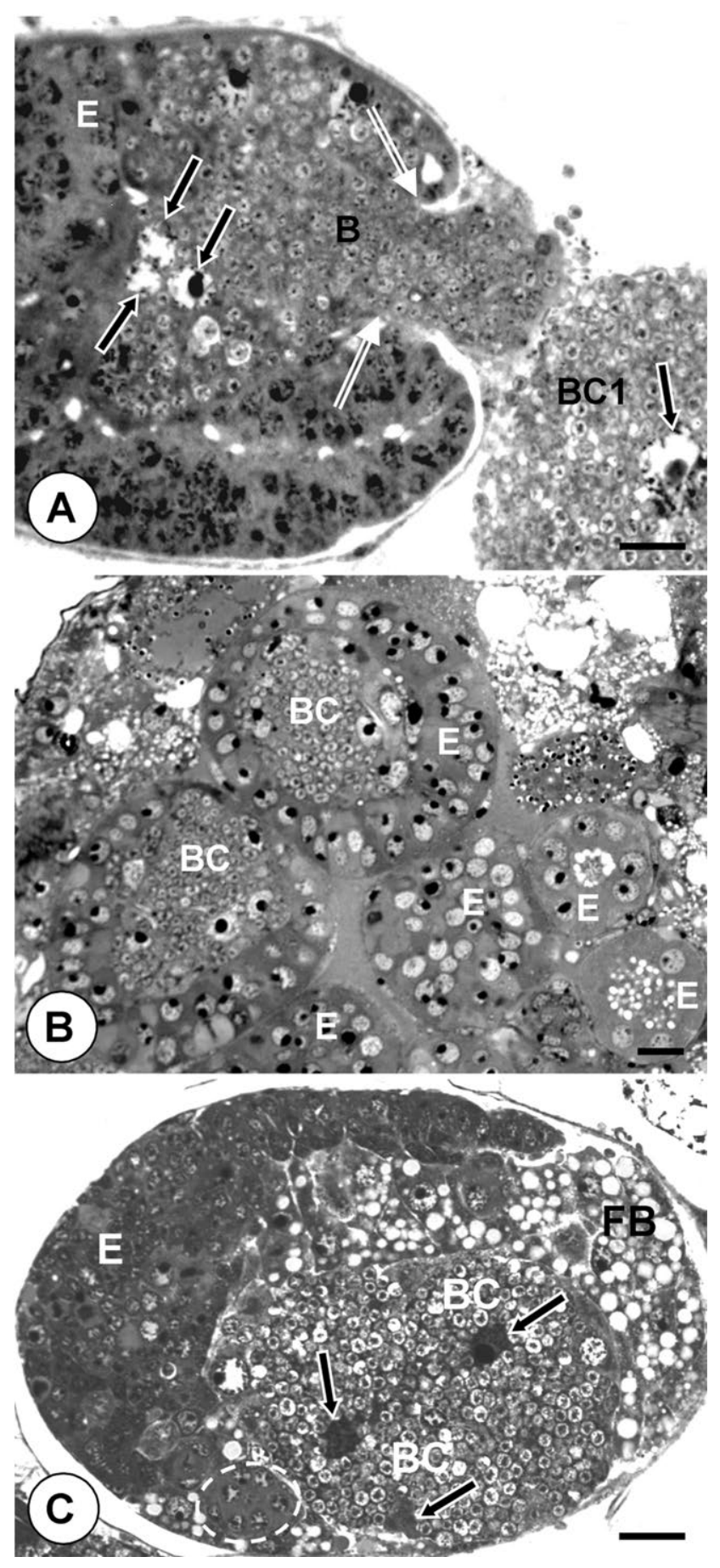

Fig. 5. Transovarial transmission of endosymbionts in viviparous generations. A - Macrosiphoniella tanacetaria (Aphididae). Viviparous generation. Bacteria infest the young embryo. Abbrev.: E - embryo, black arrow - bacteriocyte nucleus, $\mathrm{B}$ - endosymbiotic bacteria, $\mathrm{BC} 1$ - bacteriocyte with Buchnera aphidicola, double arrows indicate the opening at the posterior pole of the oocyte. Methylene blue, scale bar $-20 \mu \mathrm{m}$. B - Aphis viburni (Aphididae). Viviparous generation. Young embryos developing in the body cavity of a female. Abbrev.: $\mathrm{E}$ - embryo, BC - bacteriocyte with endosymbiotic bacteria. Methylene blue, scale bar $-20 \mu \mathrm{m}$. C - Thelaxes dryophila (Thelaxidae). Viviparous generation. Longitudinal section through a young embryo. Abbrev.: BC - bacteriocyte with endosymbiotic bacteria, E - embryo, FB - fat body, black arrow - bacteriocyte nucleus, encircled by a dotted line - ovary. Methylene blue, scale bar $-20 \mu \mathrm{m}$. infestation of embryos (in viviparous females) and oocytes (in oviparous females) is associated with a particular stage of development of the ovaries: in viviparous females bacteria invade ovarioles containing terminal embryos at the blastula stage (Figs 1, 5A), whereas in oviparous females ovarioles containing oocytes are invaded at the stage of choriogenesis (Figs 2, 6B-D). Before invasion, the bacteria leave the cytoplasm of the bacteriocytes.

In viviparous females, follicular cells surrounding the posterior pole of the embryo separate from each other, which facilitates the entry of a huge mass of bacteria into the embryo (Fig. 5A). At the time the bacteria migrate into the embryo, its interior is occupied by a syncytium containing several large nuclei of presumptive bacteriocytes (Fig. 5A). Next, the bacteria invade the cytoplasm of newly formed bacteriocytes (Figs 1, 5B). Initially, the bacteriocytes occupy the posterior pole of the embryo (Fig. 5B, C). In older embryos, the bacteriocytes gather in the vicinity of ovaries and form the bacteriome (Fig. 5C).

In oviparous females, choriogenic oocytes are invaded. Bacteriocytes assemble close to the posterior pole of the terminal oocytes (Fig. 6A). Next, endosymbiotic microorganisms are released from the bacteriocyte cytoplasm into the body cavity. In most aphids endosymbionts migrate to the perivitelline space (= space between oocyte and follicular epithelium) through wide spaces between neighbouring follicular cells (Figs 2, 6B). In the aphids Clethrobius comes (Drepanosiphidae) and Schizolachnus pineti (Lachnidae), the bacteria migrate both through spaces between neighbouring follicular cells and through the cytoplasm of follicular cells (Fig. 6C, D). From the perivitelline space they migrate into the oocyte cytoplasm (Fig. 6C, D). The entry into the ooplasm is facilitated by the absence of egg envelopes around the posterior pole of the oocyte (Figs 2, 6C, D). When the migration of endosymbionts is completed, follicular cells surrounding the posterior pole of the oocyte start to produce precursors of egg envelopes. Initially, endosymbiotic bacteria accumulate in the cortical cytoplasm at the posterior pole of the oocyte (Fig. 6E). Then they move deeper and form a characteristic "symbiont ball" (Fig. 6F, 6F insert). Endosymbiotic bacteria "wait" in the form of a symbiont ball for the beginning of embryogenesis and the formation of bacteriocytes.

\section{DISCUSSION}

Histological investigations (Kolb, 1963; Buchner, 1965 ) as well as more recent ultrastructural (e.g. Hinde, 1971; Griffiths \& Beck, 1975; Brough \& Dixon, 1990; Akhtar \& van Emden, 1994; Pyka-Fosciak \& Szklarzewicz, 2008, this study) and molecular studies (e.g. Unterman et al., 1989; Baumann et al., 1995; Fukatsu et al., 2000, 2001) have shown that aphids belonging to the superfamily Aphidoidea harbour obligatory endosymbionts. Generally it is considered that the primary symbiont in most aphid families is Buchnera aphidicola and that it is the same species in all these aphids (see Introduction) (Munson et al., 1991). An analysis of sequences of the 


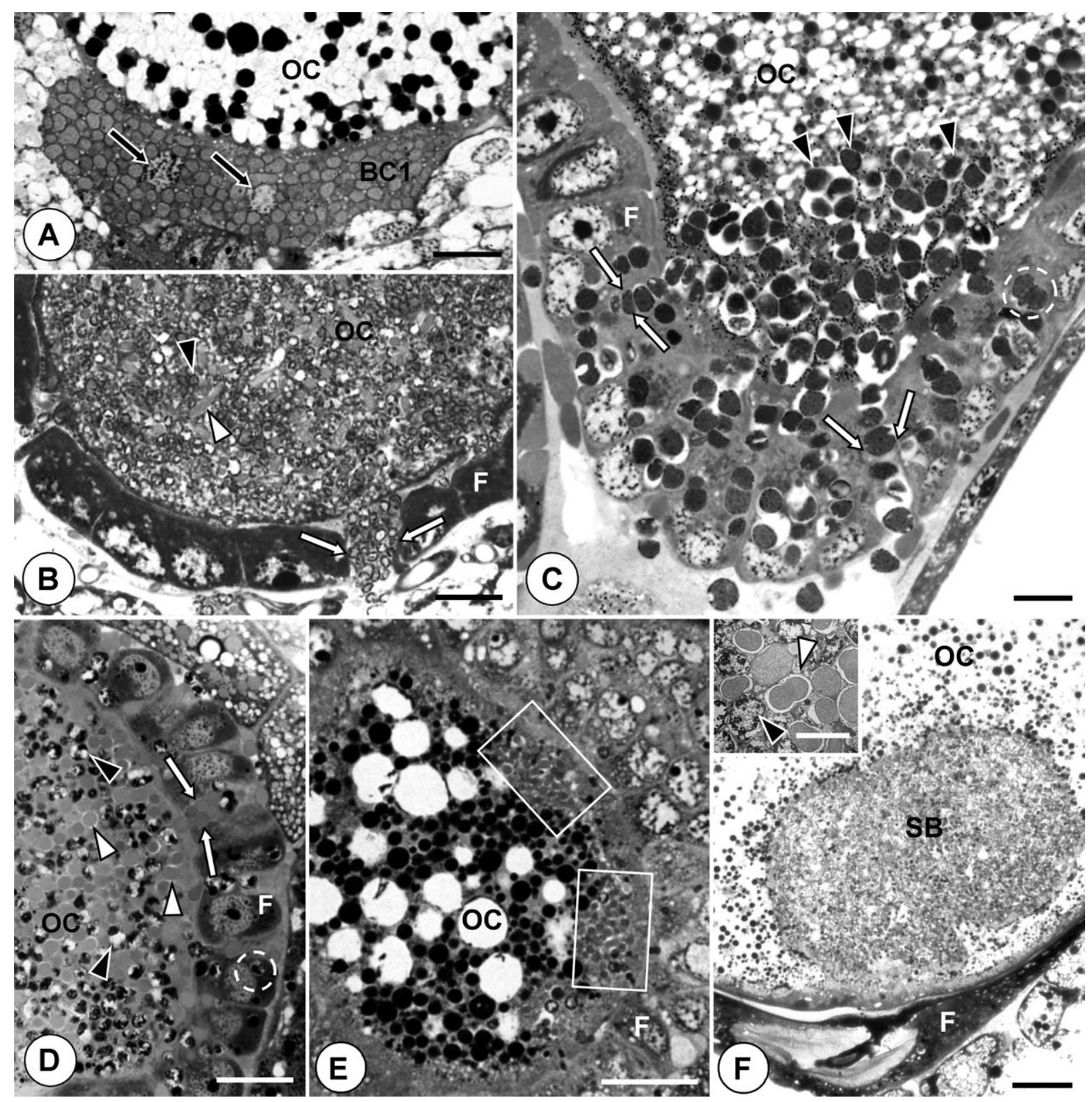

Fig. 6. Transovarial transmission of endosymbionts in oviparous generation. A - Clethrobius comes (Drepanosiphidae). Oviparous generation. Bacteriocytes with bacteria Buchnera aphidicola close to the posterior pole of the terminal oocyte. Abbrev.: BC1 - bacteriocyte with bacteria Buchnera aphidicola, OC - oocyte, black arrow - bacteriocyte nucleus. Methylene blue, scale bar - $20 \mu \mathrm{m}$. B - Sipha (Rungsia) maydis (Drepanosiphidae). Oviparous generation. Cross section through the posterior pole of the oocyte filled with primary and secondary endosymbionts. Abbrev.: OC - oocyte, F - follicular epithelium, white arrowhead - secondary endosymbiotic bacterium in the oocyte cytoplasm, black arrowhead - bacterium Buchnera aphidicola in the oocyte cytoplasm, white arrows indicate endosymbiotic bacteria migrating to the oocyte through the space between neighbouring follicular cells. Methylene blue, scale bar $-20 \mu \mathrm{m}$. C - Clethrobius comes (Drepanosiphidae). Oviparous generation. Longitudinal section through the posterior pole of the oocyte. Buchnera aphidicola bacteria migrating into the cytoplasm of an oocyte. Abbrev.: $\mathrm{F}-$ follicular epithelium, OC oocyte, black arrowheads - the bacterium Buchnera aphidicola in the cytoplasm of an oocyte, white arrows - endosymbiotic bacteria migrating into an oocyte through the space between neighbouring follicular cells, encircled - endosymbiotic bacteria migrating into an oocyte through the cytoplasm of a follicular cell. Methylene blue, scale bar $-10 \mu \mathrm{m}$. D - Schizolachnus pineti (Lachnidae). Oviparous generation. Fragment of the terminal oocyte and follicular epithelium during the migration of endosymbiotic bacteria. Abbrev.: OC - oocyte, F - follicular epithelium, white arrows indicate endosymbiotic bacteria migrating into an oocyte through the space between neighbouring follicular cells, black arrowhead - the bacterium Buchnera aphidicola in the cytoplasm of an oocyte, white arrowhead - secondary endosymbiont in the cytoplasm of an oocyte, encircled - endosymbiotic bacteria migrating into an oocyte through the cytoplasm of follicular cell. Methylene blue, scale bar - $20 \mu \mathrm{m}$. E - Anoecia (Anoecia) corni (Anoeciidae). Oviparous generation. Cross section through the choriogenic oocyte shortly after the entry of endosymbiotic bacteria into the ooplasm. Abbrev.: OC - oocyte, F - follicular epithelium, in frames - endosymbionts in the cortical cytoplasm of an oocyte. Methylene blue, scale bar - $20 \mu \mathrm{m}$. F - Lachnus roboris (Lachnidae). Oviparous generation. Longitudinal section through an oocyte containing a "symbiont ball" filled with endosymbiotic bacteria. Abbrev.: F - follicular epithelium, OC - oocyte, SB - "symbiont ball". Methylene blue, scale bar - $20 \mu \mathrm{m}$. Insert - Eulachnus rileyi (Lachnidae). Oviparous generation. Buchnera aphidicola (black arrowhead) and secondary endosymbionts (white arrowhead) in the cytoplasm of an oocyte. TEM, scale bar $-0.5 \mu \mathrm{m}$. 
16S rRNA gene from Buchnera isolated from numerous species of aphids has revealed that there are large differences (up to $17 \%$ ) in the nucleotide sequence of this gene (data from GeneBank). It is worth noting that Novákova and co-workers (2013) recently analyzed five genes (groEL, trpB, dnaB, ilvD and 16S rDNA) of B. aphidicola from 70 species of aphids and revealed that there is a great diversity of genomes of this bacterium. Therefore, Buchnera from different species of aphids may be subspecies, strains or lineages (e.g. Shigenobu et al., 2000; van Ham et al., 2003; Perez-Brocal et al., 2005; Burke et al., 2009, Novákova et al., 2013). According to Ishikawa (2003), the observed diversification of Buchnera indicates that these bacteria can not be considered as representatives of the same species. It should be added that our histological and ultrastructural observations have shown that the bacteria Buchnera present in different species of aphids exhibit significant differences in terms of the organization of their cytoplasm and size of their cells. Thus, the differences in their morphology support the conclusions of the molecular analyses.

In many species of aphid, in addition to B. aphidicola there are also secondary endosymbionts. Molecular analyses (e.g. Chen et al., 1996; Chen \& Purcell, 1997; Fukatsu et al., 2001; Gomez-Valero et al., 2004; Moran et al., 2005; Tsuchida et al., 2005) have revealed that the latter may belong to different taxa. In most species of aphids there are Gram-negative bacteria of the class Gammaproteobacteria of the family Enterobacteriaceae ( $\mathrm{Ha}$ miltonella defensa, Regiella insecticola, Serratia symbiotica, Arsenophonus), but other representatives of the Alphaproteobacteria (Rickettsia, Wolbachia) and Grampositive bacteria (Spiroplasma) may be present (see Baumann, 2005; Moran et al., 2008; Oliver et al., 2010 for further details). Moreover, in geographically isolated populations of the same aphid species several different species of secondary endosymbionts may occur (Chen et al., 1996; Chen \& Purcell, 1997; Tsuchida et al., 2002). Some of these bacteria (e.g. members of the genus Arsenophonus) are present in several species of aphids as well as in other arthropods (Darby et al., 2001; Novákova et al., 2009; Oliver et al., 2010). It should be stressed that geographically isolated populations of the same species of aphid may be devoid of secondary endosymbionts, e.g. specimens of Cinara cedri (Lachnidae) from Chile do not possess secondary endosymbionts, while European specimens of this species harbour an obligate secondary symbiont Serratia symbiotica (Perez-Brocal et al., 2006; Burke et al., 2009). Previous and present ultrastructural observations indicate that the secondary endosymbionts in the aphids studied always occur in bacteriocytes (Hinde, 1971; Griffiths \& Beck, 1975; Brough \& Dixon, 1990; Akhtar \& van Emden, 1994; Pyka-Fosciak \& Szklarzewicz, 2008; this study). As a rule, these bacteria are harboured in their own bacteriocytes. We did not find any secondary endosymbionts free in the haemolymph or in cells of the fat body.

Ultrastructural analyses have revealed that in the body of Eulachnus rileyi (Lachnidae), in addition to primary and secondary endosymbionts, there is a third type of morphologically distinct microorganism. In contrast to primary and secondary endosymbionts, these bacteria do not have own bacteriocytes and are very sparse. It should be noted that three types of endosymbionts are recorded in several other representatives of the family Lachnidae (Klevenhusen, 1927; Buchner, 1965; Gomez-Valero et al., 2004; Pyka-Fosciak, 2006; Pyka-Fosciak \& Szklarzewicz, 2008; Burke et al., 2009). The localization of the third type of microorganism in species of lachnid varies, e.g. in Eulachnus rileyi they occur together with Buchnera (this study), in Stomaphis quercus they occur in the same bacteriocytes as the secondary endosymbionts (Pyka-Fosciak \& Szklarzewicz, 2006, 2008). The actual function of these bacteria remains unknown. They may represent the evolutionary youngest endosymbionts or may be pathogenic. The size and ultrastructure of these bacteria both in Eulachnus rileyi and Stomaphis quercus seem to indicate that they may belong to the widespread species infecting arthropods, Wolbachia pipientis. This hypothesis is substantiated by the observations of GomezValero and co-workers (2004), who using molecular methods revealed that the third type of microorganism present in the body of Cinara cedri is indeed Wolbachia pipientis. It should be stressed that an earlier molecular analyses did not detect Wolbachia in aphids (Tsuchida et al., 2002). However, recent extensive studies have indicated that this bacterium occurs sporadically in some populations of representatives of several aphid families (Wang et al., 2009; Augustinos et al., 2011).

Extensive, histological investigations by Buchner (1965) and more recent ultrastructural studies (Cheng \& Hou, 2001; Szklarzewicz \& Moskal, 2001; Szklarzewicz et al., 2006, 2010, 2013; Sacchi et al., 2008; Kuechler et al., 2010, 2011; Matsuura et al., 2012; Swiatoniowska et al., 2013) have shown that during hemipteran evolution various modes of inheritance of endosymbiotic microorganisms by subsequent generations have developed. The extracellular gut bacteria that are typical of most the heteropterans so far examined (i.e. members of families Pyrrhocoridae, Plataspididae, Acanthosomatidae, Reduviidae, Pentatomidae, Scutelleridae, Coreidae, Cydnidae, Parastrachiidae and several other families of Pentatomomorpha) are as a rule vertically - postanatally transmitted either by the contamination of the eggs with the symbionts, by deposition of a special capsule filled with symbionts onto the eggs or by feeding on the mother's excrements (see e.g. Buchner, 1965; Fukatsu \& Hosokawa, 2002; Prado et al., 2006; Kaltenpoth et al., 2009; Kikuchi, 2009; Kaiwa et al., 2010; Hosokawa et al., 2010, 2013 for further details). In contrast, mycetomic bacteria of the other hemipterans (i.e. aphids, scale insects, whiteflies, psyllids, leafhoppers, planthoppers, coleorrhynchans and heteropterans belonging to families Cimicidae, Blissidae and Lygaeidae) invade female germ cells prenatally (i.e. in the ovaries of the mother) (see e.g. Buchner, 1965; Szklarzewicz \& Moskal, 2001; Szklarzewicz et al., 2006, 2010, 2013; Sacchi et al., 2008; Kuechler et al., 2012, 2013; Swiatoniowska et al., 2013 
for further details). Both the histological studies of Buchner $(1965,1966,1967)$ and more recent ultrastructural studies (Cheng \& Hou, 2001; Szklarzewicz \& Moskal, 2001; Szklarzewicz et al., 2006, 2010, 2013; Sacchi et al., 2008; Kuechler et al., 2011, 2012; Koga et al., 2012; Matsuura et al., 2012; Swiatoniowska et al., 2013) have revealed that the latter transmission of endosymbionts (termed transovarial transmission) may differ even in closely related groups of hemipterans. The endosymbiotic microorganisms may invade young germ cells termed cystocytes (i.e. before differentiation into oocytes and trophocytes) or oocytes at the stage of choriogenesis (i.e. at the end of their growth). The ovaries may be invaded by whole intact bacteriocytes or by bacteria released from the cytoplasm of bacteriocytes. Within hemipterans scale insects exhibit the greatest diversity of modes of transovarial transmission of endosymbionts (Buchner, 1965, 1966, 1967; Szklarzewicz et al., 2006, 2010, 2013; Niżnik \& Szklarzewicz, 2007). Observations on the behaviour of endosymbiont in aphids (Buchner, 1965; Braendle et al., 2003; Miura et al., 2003; Wilkinson et al., 2003; Pyka-Fosciak \& Szklarzewicz, 2008; Koga et al., 2012) have shown that these insects unlike other hemipterans are characterized by a rather uniform mode of transmission of microorganisms from mother to offspring. In all the viviparous females studied the bacteria invade embryos at the blastula stage. Recently, Koga and coworkers (2012) using electron microscopy and the FISH technique have shown that bacteria enter the embryo via exo/endocytotic transport, i.e. they are released from bacteriocytes and enter the embryonic syncytium by endocytosis. In oviparous females both primary as well as secondary endosymbionts invade ovaries containing terminal oocytes at the stage of advanced choriogenesis. In most species the bacteria migrate through the spaces between neighbouring follicular cells. Only in two species, Clethrobius comes (Drepanosiphidae) and Schizolachnus pineti (Lachnidae) do endosymbionts migrate both between neighbouring follicular cells and via the cytoplasm of these cells. In all species studied the endosymbionts enter the ooplasm and accumulate at the posterior pole of the oocyte forming a "symbiont ball". It should be noted that Pyka-Fosciak \& Szklarzewicz (2006, 2008) observed that small, rod-shaped bacteria (i.e. the third type of microorganism, see above) present in Stomaphis quercus (Lachnidae) are also maternally inherited but in contrast to the primary and secondary endosymbionts they invade larval ovaries containing undifferentiated germ cells (i.e. cystocytes). As a consequence, in the ovaries of an adult female these bacteria are present both in trophocytes and oocytes. This mode of transmission has never been observed in other aphids but is quite common in scale insects (Buchner, 1965; Niżnik \& Szklarzewicz, 2007; Szklarzewicz et al., 2010, 2013). In contrast to the situation encountered in Stomaphis quercus, the third type of microorganisms was not observed in germ cells of Eulachnus rileyi. This seems to indicate that these bacteria may be horizontally transmitted in this case.
ACKNOWLEDGEMENTS. We are greatly indebted to B. Szymańska, O. Woźnicka, D. Semik and M. Polak for their skilled technical assistance. We would like to thank the editor and two anonymous reviewers for their valuable comments. This work was supported by Research Grant K/ZDS/001962.

\section{REFERENCES}

AkHtaR S. \& VAN EMDEN H.F. 1994: Ultrastructure of the symbionts and mycetocytes of bird cherry aphid (Rhopalosiphum padi). - Tiss. Cell 26: 513-522.

Augustinos A.A., Santos-Garcia D., Dionyssopoulou E., Moreira M., Papanagiotou A., Scarvelakis M., Doudoumis V., Ramos S., Aguiar A.F., Borges P.A.V., Khadem M., Latorre A., Tsiamis G. \& Bourtzis K. 2011: Detection and characterization of Wolbachia infections in natural populations of aphids: is the hidden diversity fully unraveled? PLoS One 6: e28695.

BAUMANN P. 2005: Biology of bacteriocyte-associated endosymbionts of plant sup-sucking insects. - Annu. Rev. Microbiol. 59: $155-189$.

BAUMANN P. 2006: Diversity of prokaryote-insect associations within the Sternorrhyncha (psyllids, whiteflies, aphids, mealybugs). In Bourtzis K. \& Miller T.A. (eds): Insect Symbiosis. Vol. 2. Contemporary Topics in Entomology Series. CRC Press, Boca Raton, FL, pp. 1-24.

Baumann P., Baumann L., Lai C.Y., Rouhbakksh D., Moran N.A. \& ClaRK M.A. 1995: Genetics, physiology, and evolutionary relationships of the genus Buchnera: intracellular symbionts of aphids. - Annu. Rev. Microbiol. 49: 55-94.

Braendle C., Miura T., Bickel R., Shingleton A.W., Kambhampati S. \& Stern D.L. 2003: Developmental origin and evolution of bacteriocytes in the aphid-Buchnera symbiosis. - PLoS Biol. 1: 70-76.

Brough C.N. \& Dixon A.F.G. 1990: Ultrastructural features of egg development in oviparae of the vetch aphid, Megoura viciae Buckton. - Tiss. Cell 22: 51-63.

Buchner P. 1965: Endosymbiosis of Animals with Plant Microorganisms. Interscience Publishers, New York, London, Sydney, 909 pp.

BuCHNER P. 1966: Endosymbiosestudien an Schildläusen. VIII. Die Symbiosen der Palaeococcoidea. 1. Teil. — Z. Morphol. Ökol. Tiere 56: 275-362.

Buchner P. 1967: Endosymbiosestudien an Schildläusen. VIII. Die Symbiosen der Palaeococcoidea. 2. Teil. $-Z$. Morphol. Ökol. Tiere 59: 211-317.

BüNING J. 1985: Morphology, ultrastructure and germ cell cluster formation in ovarioles of aphids. $-J$. Morphol. 186: 209-221.

Burke G.R., Normark B.B., Favret C. \& Moran N.A. 2009: Evolution and diversity of facultative symbionts from the aphid subfamily Lachninae. - Appl. Environ. Microbiol. 75: 5328-5335.

Charles H. \& Ishikawa H. 1999: Physical and genetic map of the genome of Buchnera, the primary endosymbiont of the pea aphid Acyrthosiphon pisum. - J. Mol. Evol. 48: 142-150.

Chen D.Q., Campbell B.C. \& Purcell A.H. 1996: A new Rickettsia from a herbivorous insect, the pea aphid Acyrthosiphon pisum (Harris). - Curr. Microbiol. 33: 123-128.

Chen D.Q. \& Purcell A.H. 1997: Occurrence and transmission of facultative endosymbionts in aphids. - Curr. Microbiol. 34: $220-225$.

Cheng D.J. \& Hou R.F. 2001: Histological observations on transovarial transmission of a yeast-like symbiote in Nilaparvata 
lugens (Stål) (Homoptera, Delphacidae). — Tiss. Cell 33: 273-279.

Clark M.A., Moran N.A., Baumann P. \& Wernegreen J.J. 2000: Cospeciation between bacterial endosymbionts (Buchnera) and a recent radiation of aphids (Uroleucon) and pitfalls of testing for phylogenetic congruence. - Evolution 54: $517-525$.

Darby A.C., Birkle L.M., Turner S.L. \& Douglas A.E. 2001: An aphid-born bacterium allied to the secondary symbionts of whitefly. - FEMS Microbiol. Ecol. 36: 43-50.

von Dohlen C.D., Spaulding K.S., Havill N.P., Rosa C. \& HOOver K. 2013: Diversity of proteobacterial endosymbionts in hemlock woolly adelgid (Adelges tsugae) (Hemiptera: Adelgidae) from its native and introduced range. - Environ. Microbiol. 15: 2043-2062.

Douglas A.E. 1989: Mycetocyte symbiosis in insects. - Biol. Rev. 64: 409-434.

Douglas A.E. 1998: Nutritional interactions in insect-microbial symbioses: Aphids and their symbiotic bacteria Buchnera. Annu. Rev. Entomol. 43: 17-37.

Douglas A.E. 2003: Buchnera bacteria and other symbionts of aphids. In Bourtzis K. \& Miller T.A. (eds): Insect Symbiosis. Vol. 1. Contemporary Topics in Entomology Series. CRC Press, Boca Raton, FL, pp. 23-38.

Douglas A.E. \& Prosser W.A. 1992: Synthesis of an essential amino acid tryptophan in the pea aphid (Acyrthosiphon pisum) symbiosis. - J. Insect Physiol. 38: 565-568.

Fukatsu T. \& Hosokawa T. 2002: Capsule-transmitted gut symbiotic bacterium of the Japanese common plataspid stinkbug, Megacopta punctatissima. - Appl. Environ. Microbiol. 68: 389-396.

Fukatsu T., Nikoh N., Kawai R. \& Koga R. 2000: The secondary endosymbiotic bacterium of the pea aphid, Acyrthosiphon pisum (Insecta: Homoptera). - Appl. Environ. Microbiol. 66: 2748-2758.

Fukatsu T., Tsuchida T., Nikoh N. \& Koga R. 2001: Spiroplasma symbiont of the pea aphid Acyrthosiphon pisum (Insecta: Homoptera). - Appl. Environ. Microbiol. 67: 1284-1291.

Gomez-Valero L., Soriano-Navarro M., Perez-Brocal V., Heddi A., Moya A., Garcssa-Verdugo J.M. \& Latorre A. 2004: Coexistance of Wolbachia with Buchnera aphidicola and a secondary symbiont in the aphid Cinara cedri. $-J$ Bacteriol. 186: 6626-6633.

GRIFFITHS G.W. \& BECK S.D. 1975: Ultrastructure of pea aphid mycetocytes: evidence for symbiote secretion. - Cell Tiss. Res. 159: 351-367.

van Ham R.C.H.J., Kamerbeek J., Palacios C., Rausell C., Abascal F., Bastolla U., Fernandez J.M., Jimenez L., Postigo M., Silva F.J., Tamames J., Viguera E., Latorre A., Valencia A., Moran F. \& Moya A. 2003: Reductive genome evolution in Buchnera aphidicola. — PNAS 100: 581-586.

HINDE R. 1971: The fine structure of the mycetome symbiotes of the aphids Brevicoryne brassicae, Myzus persicae and Macrosiphum rosae. - J. Insect Physiol. 17: 2035-2050.

Hosokawa T., Kikuchi Y., NikOH N., Meng X.-Y., Hironaka M. \& Fukatsu T. 2010: Phylogenetic position and peculiar genetic traits of a midgut bacterial symbiont of the stinkbug Parastrachia japonensis. - Appl. Environ. Microbiol. 76: 4130-4135.

Hosokawa T., Hironaka M., Inadomi K., Mukai H., Nikoh N. \& FuKATSu T. 2013: Diverse strategies for vertical symbiont transmission among subsocial stinkbugs. - PLoS One 8: e65081.

HYPŠA V. \& NovÁKova E. 2009: Insect symbiosis and molecular phylogenetics. In Bourtzis K. \& Miller T.A. (eds): Insect
Symbiosis. Vol. 3. Contemporary Topics in Entomology Series. CRC Press, Boca Raton, FL, pp. 1-31.

IsHIKAWA H. 2003: Insect symbiosis: An introduction. In Bourtzis K. \& Miller T.A. (eds): Insect Symbiosis. Vol. 1. Contemporary Topics in Entomology Series. CRC Press, Boca Raton, FL, pp. 1-21.

Jousselin E., Desdevises Y. \& D’Acier A.C. 2009: Fine-scale cospeciation between Brachycaudus and Buchnera aphidicola: bacterial genome helps define species and evolutionary relationships in aphids. - Proc. Biol. Sci. 276: 187-196.

Kaiwa N., Hosokawa T., Kikuchi Y., Nikoh N., Meng X.Y., Kimura N., Ito M. \& FuKatsu T. 2010: Primary gut symbiont and secondary, Sodalis-allied symbiont of the scutellerid stinkbug Cantao ocellatus. - Appl. Environ. Microbiol. 76: 3486-3494.

Kaltenpoth M., Winter S.A. \& Kleinhammer A. 2009: Localization and transmission route of Coriobacterium glomerans, the endosymbiont of pyrrhocorid bugs. - FEMS Microbiol. Ecol. 69: 373-383.

KIKUCHI Y. 2009: Endosymbiotic bacteria in insects: Their diversity and culturability. - Microbes Environ. 24: 195-204.

Klevenhusen F. 1927: Beiträge zur Kenntnis der Aphidensymbiose. - Z. Morphol. Ökol. Tiere 41: 97-165.

Koga R., Meng X.-Y., Tsuchida T. \& Fukatsu T. 2012: Cellular mechanism for selective vertical transmission of an obligate insect symbiont at the bacteriocyte-embryo interface. PNAS 109: E1230-E1237.

Koga R., Tsuchida T. \& Fukatsu T. 2003: Changing partners in an obligate symbiosis: A facultative endosymbiont can compensate for loss of the essential endosymbiont Buchnera in an aphid. - Proc. Biol. Sci. 270: 2543-2550.

KolB G. 1963: Die Endosymbiose der Thelaxiden unter besonderer Berücksichtigung der Hormaphidinen und ihrer Embryonalentwicklung. - Z. Morphol. Ökol. Tiere 53: 185-241.

Kuechler S.M., Dettner K. \& Kehl S. 2010: Molecular characterization and localization of the obligate endosymbiotic bacterium in the birch catkin bug Kleidocerys resedae (Heteroptera: Lygaeidae, Ischnorhynchinae). - FEMS Microbiol. Ecol. 73: 408-418.

Kuechler S.M., Dettner K. \& Kehl S. 2011: Characterization of an obligate intracellular bacterium in the midgut epithelium of the bulrush bug Chilacis typhae (Heteroptera, Lygaeidae, Artheneinae). - Appl. Environ. Microbiol. 77: 2869-2876.

Kuechler S.M., Renz P., Dettner K. \& Kehl S. 2012: Diversity of symbiotic organs and bacterial endosymbionts of lygaeoid bugs of the families Blissidae and Lygaeidae (Hemiptera: Heteroptera: Lygaeoidea). - Appl. Environ. Microbiol. 78: 2648-2659.

Kuechler S.M., Gibbs G., Burckhardt D., Dettner K. \& HarTUNG V. 2013: Diversity of bacterial endosymbionts and bacteria-host co-evolution in Gondwanan relict moss bugs (Hemiptera: Coleorrhyncha: Peloridiidae). - Environ. Microbiol. 15: 2031-2042.

Lai C.-Y., Baumann L. \& Bauman P. 1994: Amplification of trpEG: Adaptation of Buchnera aphidicola to an endosymbiotic association with aphids. - Proc. Natl. Acad. Sci. USA 91: 3819-3823.

LAtorre A. \& Moya A. 2006: Comparative genomics in Buchnera aphidicola, primary endosymbiont of aphids. In Bourtzis K. \& Miller T.A. (eds): Insect Symbiosis. Vol. 2. Contemporary Topics in Entomology Series. CRC Press, Boca Raton, FL, pp. 157-174.

Liu L., Huang X.L., Zhang R.L., Jiang L.Y. \& Qiao G.X. 2013: Phylogenetic congruence between Mollitrichosiphum 
(Aphididae: Greenideinae) and Buchnera indicates insectbacteria parallel evolution. - Syst. Entomol. 38: 81-92.

Martinez-Torres D., Buades C., Latorre A. \& Moya A. 2001: Molecular systematics of aphids and their primary endosymbionts. - Mol. Phylogenet. Evol. 20: 437-449.

Matsuura Y., Kikuchi Y., Hosokawa T., Ryuichi K., Meng X.-Y., Kamagata. Y., NikOH N. \& FuKatsu T. 2012: Evolution of symbiotic organs and endosymbionts in lygaeid stinkbugs. - ISME J. 6: 397-409.

Michalik A., Szklarzewicz T., Wegierek P. \& Wieczorek K. 2013: The ovaries of aphids (Hemiptera, Sternorrhyncha, Aphidoidea): morphology and phylogenetic implications. Inv. Biol. doi: 10.1111/ivb.12026.

Miura T., Braendle C., Shingleton A., Sisk G., Kambhampat S. \& STERN D.L. 2003: A comparison of parthenogenetic and sexual embryogenesis of the pea aphid Acyrthosiphon pisum (Hemiptera: Aphidoidea). - J. Exp. Zool. (B) 295: 59-81.

Montlor C.B., Maxmen A. \& Purcell A.H. 2002: Facultative bacterial endosymbionts benefit pea aphids Acyrthosiphon pisum under heat stress. - Ecol. Entomol. 27: 189-195.

Moran N.A. \& Baumann P. 1994: Phylogenetics of cytoplasmically inherited microorganisms of arthropods. - Trends Ecol. Evol. 9: 15-20.

Moran N.A. \& Baumann P. 2000: Bacterial endosymbionts in animals. - Curr. Opin. Microbiol. 3: 270-275.

Moran N.A. \& Telang A. 1998: Bacteriocyte-associated symbionts of insects: a variety of insect groups harbor ancient prokaryotic endosymbionts. - BioScience 48: 295-304.

Moran N.A., Russell J.A., Koga R. \& FuKatsu T. 2005: Evolutionary relationships of three new species of Enterobacteriaceae living as symbionts of aphids and other insects. Appl. Environ. Microbiol. 1: 3302-3310.

Moran N.A., McCutcheon J.P. \& NaKabachi A. 2008: Genomics and evolution of heritable bacterial symbionts. Annu. Rev. Gen. 42: 165-190.

Munson M.A., Baumann P. \& Kinsey M.G. 1991: Buchnera gen. nov. and Buchnera aphidicola sp. nov. a taxon consisting of the mycetocyte-associated, primary endosymbionts of aphids. - Int. J. Syst. Bacteriol. 41: 566-568.

NiżNIK S. \& SZKLARZEwicz T. 2007: Structure and development of hermaphroditic gonad in Icerya purchasi (Insecta, Hemiptera, Coccinea: Monophlebidae). - Zool. Polon. 52: 71-90.

NormarK B.B. 2000: Molecular systematics and evolution of the aphid family Lachnidae. - Mol. Phylogenet. Evol. 14: 131-140.

Novákova E., Hypša V. \& Moran N.A. 2009: Arsenophonus, an emerging clade of intracellular symbionts with a broad host distribution. - BMC Microbiol. 9: 143.

Novákova E., Hypša V., Klein J., Foottit R.G., von Dohlen C.D. \& Moran N.A. 2013: Reconstructing the phylogeny of aphids (Hemiptera: Aphididae) using DNA of the obligate symbiont Buchnera aphidicola. - Mol. Phylogenet. Evol. 68: $42-54$.

Oliver K.M., Russel J.A., Moran N.A. \& Hunter M.S. 2003: Facultative bacterial symbionts in aphids confer resistance to parasitic wasps. - Proc. Natl. Acad. Sci. 100: 1803-1807.

Oliver K.M., Moran N.A. \& Hunter M.S. 2006: Cost and benefits of a superinfection of facultative symbionts in aphids. - Proc. R. Soc. (B) 273: 1273-1280.

Oliver K.M., Degnan P.H., Burke G.R. \& Moran N.A. 2010: Facultative symbionts in aphids and the horizontal transfer of ecologically important traits. - Annu. Rev. Entomol. 55: 247-266.

Perez-Brocal V., Latorre A., Gil R. \& Moya A. 2005: Comparative analysis of two genomic regions among four strains of Buchnera aphidicola, primary endosymbiont of aphids. Gene 345: 73-80.

Perez-Brocal V., Gil R., Ramos S., Lamelas A., Postigo M., Michelena J.M., Silva F.J., Moya A. \& Latorre A. 2006: A small microbial genome: the end of a long symbiotic relationship? - Science 314: 312-313.

Perez-Brocal V., Gil R., Moya A. \& Latorre A. 2011: New insights on the evolutionary history of aphids and their primary endosymbiont Buchnera aphidicola. - Int. J. Evol. Biol. doi: 10.4061/2011/250154.

Prado S.S., Rubinoff D. \& Almeida R.P.P. 2006: Vertical transmission of a pentatomid caeca-associated symbiont. - Ann. Entomol. Soc. Am. 99: 577-585.

PYKa-Fosciak G. 2006: Structure and Development of the Female Gonad in Oviparous and Viviparous Generations of aphid Stomaphis quercus (Hemiptera, Aphidinea: Lachnidae). Ph.D. Thesis, Jagiellonian University, 87 pp. [in Polish].

Pyka-Fosciak G. \& Szklarzewicz T. 2008: Germ cell cluster formation and ovariole structure in viviparous and oviparous generation of the aphid Stomaphis quercus. - Int. J. Dev. Biol. 52: 259-265.

Sacchi L., Genchi M., Clementi E., Bigliardi E., Avanzatti A.M., Pajoroi M., Negri I., Marzorati M., Gonella E., Alma A., DafFonchio D. \& BAndi C. 2008: Multiple symbiosis in the leafhopper Scaphoideus titanus (Hemiptera: Cicadellidae): Details of transovarial transmission of Cardinium sp. and yeast-like endosymbionts. - Tiss. Cell 40: 231-242.

Sandström J.P., Russell J.A., White J.P. \& Moran N.A. 2001: Independent origins and horizontal transfer of bacterial symbionts of aphids. - Mol. Ecol. 10: 217-228.

Sasaki T. \& Ishikawa H. 1995: Production of essential amino acids from glutamate by mycetocyte symbiont of the pea aphid Acyrthosiphon pisum. - J. Insect Physiol. 41: 41-46.

Scarborough C.L., Ferrari J. \& Godfray H.C.J. 2005: Aphid protected from pathogen by endosymbiont. - Science 310: 1781.

Shigenobu S., Watanabe H., Hattori M., Sakaki Y. \& Ishikawa H. 2000: Genome sequence of the endocellular bacterial symbiont of aphids Buchnera sp. APS. - Nature 407: 81-86.

Swiatoniowska M., Ogorzalek A., Golas A., Michalik A. \& SzKLARZEWICZ T. 2013: Ultrastructure, distribution and transovarial transmission of symbiotic microorganisms in Nysius ericae and Nithecus jacobaeae (Heteroptera: Lygaeidae: Orsillinae). - Protoplasma 250: 325-332.

SzKLARzewicz T. \& Moskal A. 2001: Ultrastructure, distribution, and transmission of endosymbionts in the whitefly Aleurochiton aceris Modeer (Insecta, Hemiptera, Aleyrodinea). - Protoplasma 218: 45-53.

SzKLARZEWicz T., WNĘK A. \& BilińSKi S.M. 2000: Structure of ovarioles in Adelges laricis, representative of the primitive aphid Adelgidae. - Acta Zool. (Stockholm) 81: 307-313.

SZKLARZEWICZ T., KĘDRA K. \& NiżNIK S. 2006: Ultrastructure and transovarial transmission of endosymbiotic microorganisms in Palaeococcus fuscipennis (Burmeister) (Insecta, Hemiptera, Coccinea: Monophlebidae). — Folia Biol. (Kraków) 54: 70-74.

Szklarzewicz T., Jankowska W., Wieczorek K. \& Wegierek P. 2009: Structure of the ovaries of the primitive aphids Phylloxera coccinea and Phylloxera glabra (Hemiptera, Aphidinea: Phylloxeridae). — Acta Zool. (Stockholm) 90: 123-131.

Szklarzewicz T., Michalik A., Czaja A. \& SzydŁowska S. 2010: Germ cell cluster formation and ovariole structure in Puto albicans and Crypticerya morrilli (Hemiptera: Coccinea). Phylogenetic implications. - Eur. J. Entomol. 107: 589-595. 
SzKlarzewicz T., KalandyK-KolodZIEJCZyK M., Kot M. \& MichALIK A. 2013: Ovary structure and transovarial transmission of endosymbiotic microorganisms in Marchalina hellenica (Insecta, Hemiptera, Coccomorpha: Marchalinidae). Acta Zool. (Stockholm) 94: 184-192.

Thao M.L. \& Baumann P. 2004: Evidence for multiple acquisition of Arsenophonus by whitefly species (Sternorrhyncha: Aleyrodidae). - Curr. Microbiol. 48: 140-144.

Toenshoff E.R., Penz T., Narzt T., Collingro A., SchmitzEsser S., Pfeifer S., Klepal W., Wagner M., Wienmaier T., RAtTei T. \& Horn M. 2012a: Bacteriocyte-associated gammaproteobacterial symbionts of the Adelges nordmannianael piceae complex (Hemiptera: Adelgidae). - ISME J. 6: 384-396.

Toenshoff E.R., Gruber D. \& Horn M. 2012b: Co-evolution and symbiont replacement shaped the symbiosis between adelgids (Hemiptera: Adelgidae) and their bacterial symbionts. - Environ. Microbiol. 14: 1284-1295.

Tsuchida T., Koga R., Shibao H., Matsumoto T. \& Fukatsu T. 2002: Diversity and geographic distribution of secondary endosymbiotic bacteria in natural populations of the pea aphid Acyrthosiphon pisum. - Mol. Ecol. 11: 2123-2135.

Tsuchida T., Koga R., Meng X.-Y., Matsumoto T. \& Fukatsu T. 2005: Characterization of a facultative endosymbiotic bacterium of the pea aphid Acyrthosiphon pisum. - Microbiol. Ecol. 49: 126-133.

Unterman B.M., Baumann P. \& McLean D.L. 1989: Pea aphid symbiont relationships established by analysis of $16 \mathrm{~S}$ rRNAs. — J. Bacteriol. 171: 2970-2974.

Vorburger C., Gehrer L. \& Rodriguez P. 2010: A strain of the bacterial symbiont Regiella insecticola protects aphids against parasitoids. - Biol. Lett. 6: 109-111.

Wang Z., Shen Z.-R., Song Y., Liu H.-Y. \& Li Z.-X. 2009: Distribution and diversity of Wolbachia in different populations of the wheat aphid Sitobion miscanti (Hemiptera: Aphididae) in China. - Eur. J. Entomol. 106: 49-55.

WiLKINSON T.L., FuKatsu T. \& IshiKaWA H. 2003: Transmission of symbiotic bacteria Buchnera to parthenogenetic embryos in the aphid Acyrthosiphon pisum (Hemiptera: Aphidoidea). - Arthr. Struct. Dev. 32: 241-245.

Received March 7, 2013; revised and accepted July 7, 2013 